The Israeli Journal of Aquaculture - Bamidgeh •ISSN 0792-156X •IJA.74.2022.1553557, 9 pages

CCBY-NC-ND-4.0 • https://doi .org/10.46989/001c.33012

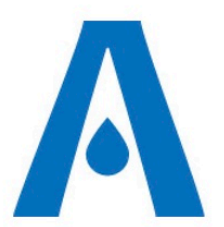

The IJA is a peer-reviewed open-access, electronic journal, freely available without charge to users

Produced by the AquacultureHub non-profit Foundation

Sale of IJA papers is strictly forbidden

\title{
The effect of water temperature on the pathogenicity of decapod iridescent virus 1 (DIV1) in Litopenaeus vannamei
}

\author{
Xuzheng Liao ${ }^{1,2}{ }^{+}$, Yuqin Su ${ }^{3,}{ }^{+}$, Bo Wang ${ }^{1}$, Haipeng Qin ${ }^{1}$, Shikang Hu ${ }^{1}$, Jichen \\ Zhao $^{1}$, Zihao $\mathrm{He}^{1}$, Xieyan Chen ${ }^{1}$, Zhaojian Lin ${ }^{5}$, Yongkui Liu ${ }^{5}$, Lilin Xiao ${ }^{5}$, Cheng- \\ Bo Sun ${ }^{1,4}, *$ \\ ${ }^{1}$ College of Fisheries, Guangdong Ocean University, Zhanjiang, P. R. China \\ 2 Southern Marine Science and Engineering Guangdong Laboratory (Zhuhai)/ State Key Laboratory \\ of Biocontrol, School of Marine Sciences, Sun Yat-sen University, Guangzhou, PR China \\ 3 School of Life Sciences, Sun Yat-sen University, Guangzhou, PR China \\ 4 Guangdong Provincial Key Laboratory of Pathogenic Biology and Epidemiology for Aquatic \\ Economic Animals, Zhanjiang, PR China \\ ${ }^{5}$ Haimao Seed Technology Group Co., LTD, Zhanjiang, PR China
}

Keywords: Water temperature, Litopenaeus vannamei, decapod iridescent virus 1, viral copy count, survival rate

\begin{abstract}
Decapod iridescent virus 1 (DIV1) has caused huge losses to the shrimp breeding industry in recent years as a new shrimp virus. In this study, white leg shrimp, Litopenaeus vannamei, were cultured at different temperatures (26 $\pm 1^{\circ} \mathrm{C}$ and $32 \pm 1^{\circ} \mathrm{C}$ ) and the same salinity, then infected with DIV1 by intramuscular injection to determine the effects of water temperature on viral infection. The DIV1 copy counts in the gills, hepatopancreas, pleopods, intestines, and muscles of $L$. vannamei were measured in samples collected at 6,12 , and $24 \mathrm{~h}$ post-infection (hpi), and the survival rate of $L$. vannamei was assessed every $6 \mathrm{~h}$ after infection. At $96 \mathrm{hpi}$, the survival rates of $L$. vannamei in the high $\left(32 \pm 1{ }^{\circ} \mathrm{C}\right)$ and standard $\left(26 \pm 1^{\circ} \mathrm{C}\right)$ water temperature groups were $2.22 \%$ and $4.44 \%$, respectively. The peak time of mortality in the high-water temperature group was $6 \mathrm{~h}$ earlier than in the standard water temperature group. After 24 hours of DIV1 infection, the DIV1 copy counts in the standard water temperature treatment group were significantly higher than those in the high-water temperature treatment group. The tissues with the highest virus copy counts in the standard and high-temperature groups were the intestines $\left(2.9 \times 10^{11} \mathrm{copies} / \mathrm{g}\right)$ and muscles $\left(7.0 \times 10^{8} \mathrm{copies} / \mathrm{g}\right)$. The effect of temperature on the pathogenicity of DIV1 differs from that of other previously studied viruses, such as white spot syndrome virus, Taura syndrome virus, and infectious hypodermal and hematopoietic necrosis virus, because the highwater temperature did not mitigate the damage caused by DIV1 infection.
\end{abstract}

* Corresponding author. Tel.: place telephone number here (optional), fax: fax number here (optional), e-mail: email address here (required) Cheng-bo Sun, Tel.: +86 7592383236, fax: +86 7592383124, e-mail: suncb@gdou.edu.cn;

† These authors contributed equally to this work. 


\section{Introduction}

Litopenaeus vannamei is an important and the most farmed aquaculture species globally (Hernandez-Palomares M. L. E. et al., 2018). In China, the current annual shrimp production exceeds 1.5 million metric tons, accounting for almost one-third of global shrimp output (Li C. et al. 2019). As shrimp production has grown, outbreaks of various diseases caused by protozoa, fungi, bacteria, and viruses have also increased significantly (Thitamadee S. et al., 2016). Viral infections are the most serious of all shrimp illnesses. White spot disease and Taura syndrome are widespread viral illnesses that affect shrimp (Walker P. J. et al., 2009). Viral diseases cause enormous economic aquaculture losses and severely affect aquaculture development (Lightner D. V. et al., 1999). Thus, understanding shrimp viral infections is essential both now and in the future of aquaculture. In 2014, many L. vannamei died in dense farming areas in Pinghu City, Zhejiang Province. The symptoms of the diseased shrimp included empty stomachs and guts, a slight loss of surface color, hepatopancreas damage, and fragile shells in some infected shrimps. Nested PCR results showed that they were infected with decapod iridescent virus 1 (DIV1) of the family Iridoviridae (Qiu L. et al., 2017).

Iridoviridae have broad host ranges and infect both vertebrates and invertebrates. Iridoviridae can infect insects, amphibians, and fishes. They are widely distributed among aquatic species and can result in massive losses (Chinchar V. G. et al., 2009). In 2017, the Yellow Sea Fisheries Research Institute of the Chinese Academy of Fishery Sciences isolated a novel virus from collected samples. Histopathology revealed phlegm inclusion bodies and pyknosis in hematopoietic tissues and the blood cells of the gills, hepatopancreas, pleopods, and muscles. Polygenetic analysis of the amino acid sequence of its major capsid protein (MCP) and ATPase showed that it belonged to the family iridoviridae but not to any known category (Xu L. et al., 2016). As a result, this virus was given the temporary designation DIV1 (Qiu L. et al., 2019). Researchers found that infected farmed $L$. vannamei had a significant death rate, with 100 percent death occurring within 15 days. The ill shrimp sunk to the bottom due to weak swimming abilities. Researchers have sequenced the complete genome of DIV1 and established TaqMan-based real-time PCR assays to detect and quantify DIV1 (Qiu L. et al., 2018). The detection limit of this method is 4 copies/ $\mu$ l. With the advantages of high sensitivity and specificity, it is a convenient assay to quantify DIV1 accurately (Qiu L. et al., 2017).

Shrimp are poikilothermic creatures, which means they have no systems for controlling their body temperature. As a result, the ambient temperature determines their body temperature (Suantika G., 2013). Many key enzymatic activities are affected by body temperature. Heat shock proteins (HSPs) are induced in response to changes in ambient temperature, a process known as the heat shock stress response (Parsell D. A. et al., 1993). Although heat shock responses are up-regulated by heat exposure, they are universal to all cells and stressors, including heat, toxins, protein degradation, hypoxia, and microbial infection (Becker J. et al., 1994). Temperature fluctuations can also affect shrimp's physiological activities, such as growth (Wyban J. et al., 1995), disease resistance (Cheng W. et al., 2005), and metabolic rates (Allan E. L. et al., 2006). Furthermore, investigations have revealed that temperature influences the replication rates of various shrimp viruses (Kan L. I. et al., 2013).

Scholars in China and elsewhere have investigated the impact of water temperature on shrimp, including the effect of water temperature on shrimp development and eating, as well as changes in immunological responses. Fluctuations in water temperature can make shrimp more susceptible to illness by decreasing their resistance. According to Wyban et al., the ideal water temperature for shrimp is $23-30{ }^{\circ} \mathrm{C}$ (Wyban J. A. et al., 1995). The shrimp were shocked when the water temperature was reduced to $15-22{ }^{\circ} \mathrm{C}$ or raised to $30-33^{\circ} \mathrm{C}$. Researchers also have studied the effect of temperature on epidemic viruses in shrimp. As a result, warm water reduced the mortality of shrimp infected with white spot syndrome virus (WSSV) (Vidal O. M. et al., 2001) and Taura syndrome virus (TSV) (Côté I. et al., 2010). It inhibited the multiplication of WSSV (Moser J. R. et al., 2012), TSV (Côté I. et al., 2010), and infectious hypodermal and hematopoietic necrosis virus (IHHNV) 
(Montgomery-Brock D. et al., 2007). When the water temperature was maintained at 21$30{ }^{\circ} \mathrm{C}$, the virus multiplied rapidly, but it was inhibited to some extent at the other temperatures examined (Kan L. I. et al., 2013).

There have been no studies on the effect of temperature on $L$. vannamei infected with DIV1. Therefore, the purpose of this study was to determine whether high water temperature affected the function of DIV1. Viral multiplication in different tissues and the survival rate of $L$. vannamei were assessed in this study. Previous studies showed that increasing the temperature of aquaculture water inhibits the growth and survival of WSSV, TSV, and IHHNV. Therefore, this study investigated the effects of high-water temperature on DIV1 s proliferation and pathogenicity.

\section{Materials and Methods}

\section{Rearing condition}

L. vannamei (mean body length, $6.70 \pm 0.67 \mathrm{~cm}$ and mean body weight, $3.58 \pm 1.0 \mathrm{~g}$ ) were purchased from Guangdong Haimao Aquatic Seed Industry Technology Co., Ltd. (Zhanjiang, Guangdong, China). They were randomly sampled and tested by PCR to ensure they were free from IHHNV, WSSV, and DIV1. Shrimp naturally infected with DIV1 were obtained from a farm in Wuchuan, Guangdong, China, and the virus was extracted from the tissues of an infected $L$. vannamei (Ye T. et al., 2012). The shrimp were fed commercial feed twice a day for 1 week in $0.3 \mathrm{~m}^{3}$ tanks with aerated and filtered freshwater at East Island Marine Biological Research Base, Guangdong Ocean University (Zhanjiang, Guangdong, China). The water temperature was adjusted to the experimental temperatures $\left(26 \pm 1\right.$ and $\left.32 \pm 1^{\circ} \mathrm{C}\right)$.

\section{DIV1 extractive and sample collection}

DIV1 was extracted from naturally infected $L$. vannamei. Briefly, $5-10 \mathrm{~g}$ of tissue from naturally infected $L$. vannamei was diluted $1: 2$ with sterile PBS and then homogenized at $1000 \times \mathrm{g}$ for $5-10 \mathrm{~s}$ in an ice bath. The homogenate was transferred to a centrifuge tube and then centrifuged for $10 \mathrm{~min}$ at $8000 \times \mathrm{g}$. The supernatant was filtered through a 0.45 $\mu \mathrm{m}$ filter and intramuscularly injected into healthy $L$. vannamei. The experimental groups (maintained at $26 \pm 1$ and $32 \pm 1^{\circ} \mathrm{C}$ ) were administered $50 \mu \mathrm{L}$ of DIV1 extract (containing $1.0 \times 10^{4}$ copies/ $\mu \mathrm{l}$ ) by intramuscular injection. The control groups, maintained at the same temperatures, were injected with $50 \mu \mathrm{L}$ of PBS. Three parallel groups were incubated at each temperature, and each group contained 30 shrimp. During the experiment, shrimp were fed commercial feed twice a day, and water was renewed at $\sim 50 \%$ daily. At 6,12 , and $24 \mathrm{~h}$ post-infection (hpi), three shrimp from each temperature were randomly removed for sample collection. The gills, hepatopancreas, pleopods, intestines, and muscles were collected. The collected samples were immediately placed into a $-80^{\circ} \mathrm{C}$ freezer (Fouzi M. et al., 2010). Dead L. vannamei were removed as soon as possible. The survival rate of each group was calculated every $6 \mathrm{~h}$.

\section{DNA extraction and DIV1 nested PCR assay}

According to the manufacturer's instructions, total shrimp genomic DNA was extracted from $30 \mathrm{mg}$ of a sample using the EasyPure Marine Animal Genomic DNA Kit (TransGen, Beijing, China). After extraction, the DNA concentration was determined with a SimpliNano spectrophotometer (GE Healthcare, USA). Primers were designed using Primer Premier 5 software (Table 1). Each $20 \mu \mathrm{L}$ nested PCR contained $10 \mu \mathrm{L}$ of $2 \times$ PCR Taq Mastermix, 7 $\mu \mathrm{L}$ of $\mathrm{ddH}_{2} \mathrm{O}, 1 \mu \mathrm{L}$ of Primer $\mathrm{F}, 1 \mu \mathrm{L}$ of Primer R, and $1 \mu \mathrm{L}$ of a template. The PCR program was as follow $95^{\circ} \mathrm{C}$ for 5 min, followed by 34 cycles of $95^{\circ} \mathrm{C}$ for $30 \mathrm{~s}, 55^{\circ} \mathrm{C}$ for $45 \mathrm{~s}$, and $72{ }^{\circ} \mathrm{C}$ for $1 \mathrm{~min}$, and a final extension step at $72{ }^{\circ} \mathrm{C}$ for $10 \mathrm{~min}$. The amplification products were evaluated by $1.5 \%$ agarose gel electrophoresis. 
Table 1 The primers and TaqMan probes for decapod iridescent virus 1 (DIV1).

\begin{tabular}{cc}
\hline Primer names & Sequences (5'-3') \\
\hline DIVI-F & GGGCGGGAGATGGTGTTAGAT \\
DIVI-R & TCGTTTCGGTACGAAGATGTA \\
qRT-DIV1-F & ATGAAACAGAAAACATTCCCCA \\
qRT-DIV1-R & TTTCACACTTCCTGATAGTCTTCCAT \\
TaqMan Probe & TCACAGAAAAGATTCCCGAAATGGTAAAAC
\end{tabular}

TaqMan-based quantitative real-time $P C R$

DIV1 genomic DNA was used as the template for qPCR. The primers used in the analysis are listed in Table 1. Each qPCR reaction mix contained $10 \mu \mathrm{L}$ of Probe qPCR Mix $(2 \times)$, $0.4 \mu \mathrm{L}$ of PCR forward primer $(10 \mu \mathrm{M}), 0.4 \mu \mathrm{L}$ of PCR reverse primer $(10 \mu \mathrm{M}), 0.8 \mu \mathrm{L}$ of the probe, $2 \mu \mathrm{L}$ of template, and $6.4 \mu \mathrm{L}$ of $\mathrm{H}_{2} \mathrm{O}$. The qPCR was conducted in a LightCycler 96 as follows: preincubation at $95^{\circ} \mathrm{C}$ for $30 \mathrm{~s}$, followed by 40 cycles of 2 step amplification at $95^{\circ} \mathrm{C}$ for $5 \mathrm{~s}$ and $55^{\circ} \mathrm{C}$ for $30 \mathrm{~s}$ and then $95^{\circ} \mathrm{C}$ for $5 \mathrm{~s}, 60^{\circ} \mathrm{C}$ for $60 \mathrm{~s}$, and $95^{\circ} \mathrm{C}$ for $1 \mathrm{~s}$. The final step was cooling at $50^{\circ} \mathrm{C}$ for $30 \mathrm{~s}$.

According to the published method, a standard curve for quantification was constructed (Qiu L. et al., 2018). The target plasmid was serially diluted (10-fold, $\left.4 \times 10^{8}-4 \times 10\right)$. Then, the plasmid copy count was calculated using a formula. The diluted plasmid solutions were used as a DNA template for qPCR. Finally, a standard curve of the relationship between the Ct value and copy count was generated.

\section{Statistical analysis}

The average percent survival and virus genome copy counts are the mean, standard deviation (SD). For the real-time PCR, the results of three replicates of each sample are expressed as the mean \pm SD. The data were analyzed by one-way ANOVA followed by Dunnett's test. $P$ values less than 0.05 were considered statistically significant.

\section{Results}

Standard curve of quantitative real-time PCR

Based on the relationship between the plasmid copy count and the $\mathrm{Ct}$ value, we generated the following standard curve: $\mathrm{Ct}=-3.3358 \mathrm{X}+44.362$ ( $\mathrm{X}$ is the $\log _{10}$ concentration (DNA copies)). The correlation index $\left(R^{2}\right)$ was 0.9996 (Figure 1 and 2 ).

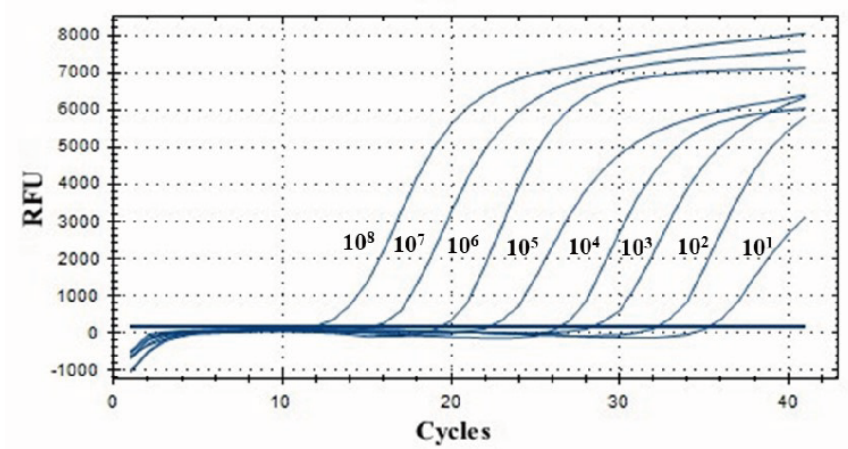

Figure 1 Real-time quantitative PCR amplification curves of a 10-fold dilution series. The target plasmid was serially diluted 10 -fold $\left(4 \times 10^{8}-4 \times 10\right)$ and subjected to Real-time quantitative PCR. 


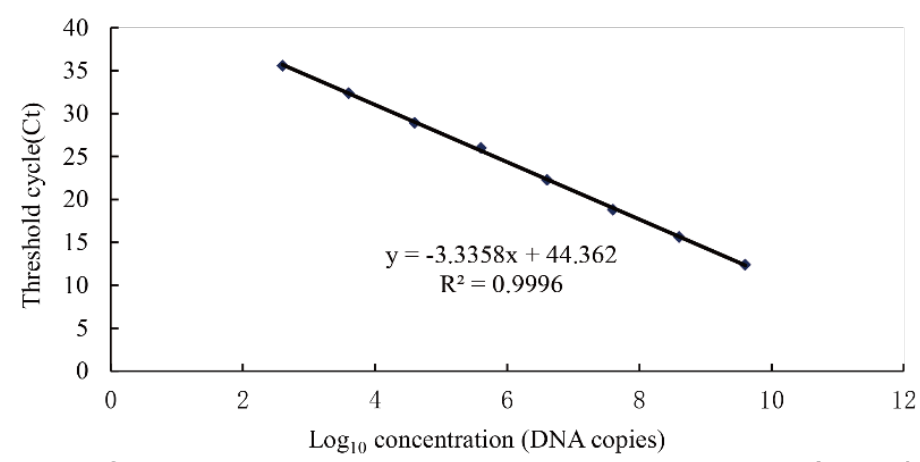

Figure 2 Standard curve of quantitative PCR. Ct $=-3.3358 X+44.362$ ( $X$ is the $\log _{10}$ concentration (DNA copies)). The correlation index $\left(R^{2}\right)$ is 0.9996 . The copy count of the recombinant plasmid=plasmid concentration $\times$ Avogadro's number/recombinant plasmid molecular weight. Avogadro's number is $6.02 \times 10^{23}$. The molecular weight of recombinant plasmid $=$ average molecular weight of 1 base pair $(660 \mathrm{~g} / \mathrm{mol}) \quad$ total length of recombinant plasmid (bp).

\section{Survival rate}

During the experimental period, the survival rate of $L$. vannamei continuously decreased. There was a highly significant difference between the experimental (infected) and control (uninfected) groups at the same water temperature $(P<0.01)$. The survival rates of the experimental groups at $96 \mathrm{hpi}$ were significantly lower than those of the control uninfected groups. The survival rate of the $26 \pm 1^{\circ} \mathrm{C}$ infected group was $4.44 \%$, while that of the $26 \pm 1{ }^{\circ} \mathrm{C}$ control group was $78.89 \%$. The survival rate of the $32 \pm 1{ }^{\circ} \mathrm{C}$ infected group was $2.22 \%$, while that of the $32 \pm 1{ }^{\circ} \mathrm{C}$ control group was $86.67 \%$. The survival rates of the $26 \pm 1{ }^{\circ} \mathrm{C}$ and $32 \pm 1{ }^{\circ} \mathrm{C}$ infected groups showed no significant difference $(P>$ $0.05)$, and both of them were less than $5 \%$. The peak dying time of the $32 \pm 1{ }^{\circ} \mathrm{C}$ infected group, at $12 \mathrm{hpi}$, was $6 \mathrm{~h}$ earlier than that of the $26 \pm 1^{\circ} \mathrm{C}$ infected group (18 hpi). The former decreased from $94.44 \%$ to $10.00 \%$, and the latter decreased from $94.44 \%$ to $2.22 \%$. The survival rate of the low temperature $\left(26 \pm 1{ }^{\circ} \mathrm{C}\right)$ infected group stabilized at $48 \mathrm{hpi}$, and that of the $32 \pm 1^{\circ} \mathrm{C}$ infected group stabilized at $30 \mathrm{hpi}$ (Figure 3 ).

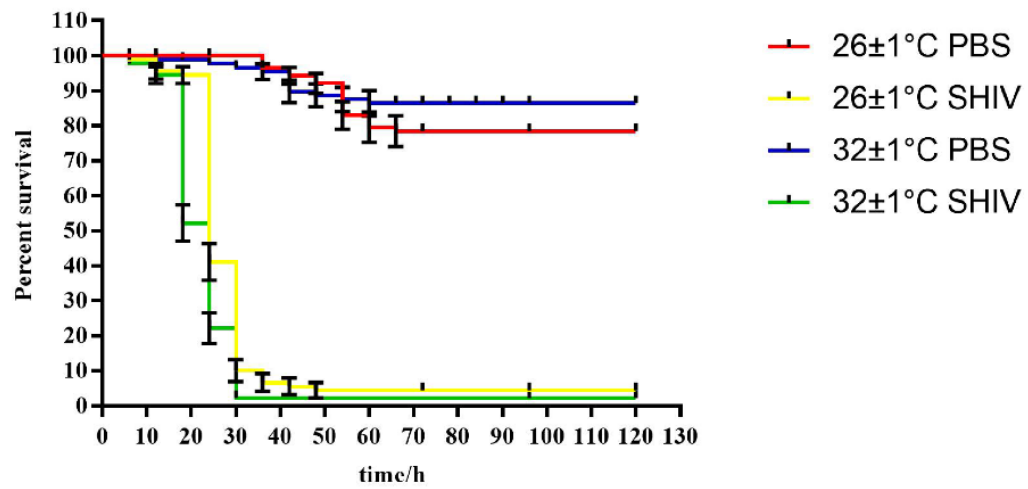

Figure 3 Effect of temperature on the survival rate of $L$. vannamei infected with DIV1. After an acclimation at either $26 \pm 1{ }^{\circ} \mathrm{C}$ or $32 \pm 1{ }^{\circ} \mathrm{C}$, L. vannamei was injected intramuscularly with DIV1. The mortality in each group $(n=30)$ was recorded every 6 hpi. Kaplan-Meier log-rank $x 2$ tests analyzed differences in cumulative mortality between the experimental and control groups.

The proliferation of DIV1 under different water temperatures in gill, hepatopancreas, pleopod, intestine, muscle

qPCR analysis showed that the DIV1 copy counts in other tissues of the infected shrimp constantly accumulated. At $26 \pm 1{ }^{\circ} \mathrm{C}$, the DIV1 copy counts in each infected tissue differed remarkably at 6 and 24 hpi $(P<0.01)$. DIV1 replicated fastest in the intestines, where it was detected in the highest quantity. It increased from $2.9 \times 10^{7} \mathrm{copies} / \mathrm{g}$ at $6 \mathrm{hpi}$ to $2.9 \times 10^{11}$ copies/g at $24 \mathrm{hpi}$ (Figure 4). Correspondingly, each tissue sampled at $32 \pm 1$ 
${ }^{\circ} \mathrm{C}$ also differed significantly at 6 and 24 hpi $(P<0.01)$. Among these tissues, the muscles showed the highest viral load (Figure 5).

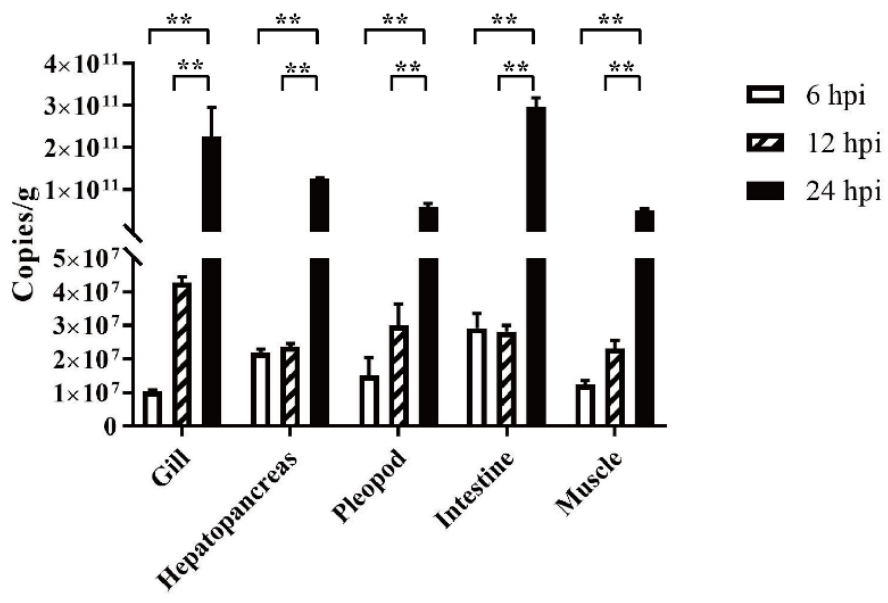

Figure 4 DIV1 copy counts in the gills, hepatopancreas, pleopods, intestines, and muscles at different time points at $26 \pm 1{ }^{\circ} \mathrm{C}$. The virus copy counts in each tissue were measured in samples collected at 6, 12, and $24 \mathrm{hpi}$.

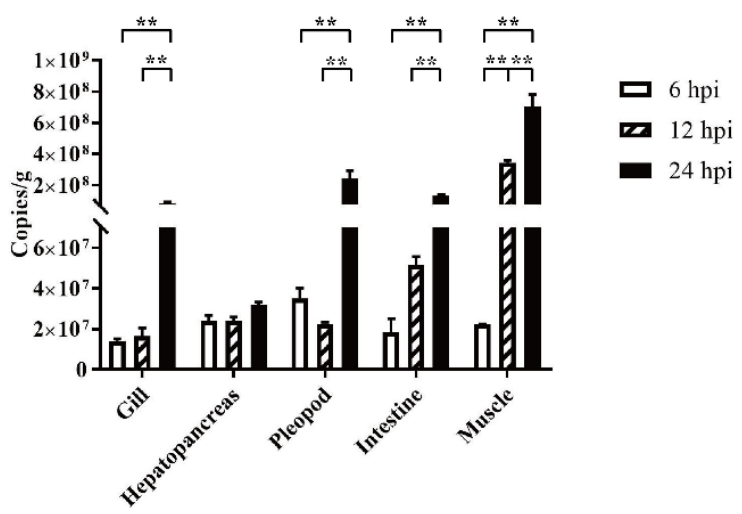

Figure 5 DIV1 copy counts in the gills, hepatopancreas, pleopods, intestines, and muscles at different time points at $32 \pm 1{ }^{\circ} \mathrm{C}$. The virus copy counts in each tissue were measured in samples collected at 6, 12, and $24 \mathrm{hpi}$.

DIV1 replicated at different rates in the two different water temperatures. Except in the intestine, the DIV1 copy counts in the sampled tissues were higher at $32 \pm 1{ }^{\circ} \mathrm{C}$ than at 26 $\pm 1^{\circ} \mathrm{C}$ at $6 \mathrm{hpi}$. The differences in the DIV1 copy counts in the gills, pleopods, and muscles were highly significant $(P<0.01)$. At $12 \mathrm{hpi}$, the copy counts in the intestines and muscles were significantly higher at $32 \pm 1{ }^{\circ} \mathrm{C}$ than at $26 \pm 1{ }^{\circ} \mathrm{C}(P<0.01)$. However, at $24 \mathrm{hpi}$, the DIV1 copy counts in the gills, hepatopancreas, pleopods, and intestines at $26 \pm 1{ }^{\circ} \mathrm{C}$ were much higher than those at $32 \pm 1{ }^{\circ} \mathrm{C}(\mathrm{P}<0.01)$, whereas the DIV1 copy count in the muscles was much higher at $32 \pm 1{ }^{\circ} \mathrm{C}$ than at $26 \pm 1{ }^{\circ} \mathrm{C}(P<0.01)$.

\section{Discussion}

In recent years, various diseases in farmed $L$. vannamei have led to massive economic losses in China (Tran L. et al., 2013). In this study, we investigated the effects of temperature on the infection of a new iridovirus, DIV1. The results indicated that DIV1 is extremely harmful to $L$. vannamei. Remarkable differences were observed in survival and 
viral copy count between the DIV1-infected and PBS-treated groups at the two tested water temperatures. For both high and normal water temperatures, the survival of DIV1-infected shrimp fell to $5 \%$ by $30 \mathrm{hpi}$. This result does not contradict previous studies of DIV1 reported as a highly pathogenic virus (Qiu L. et al., 2017). The possible explanations for the high pathogenicity of DIV1 might be related to the immune responses.

The host immune responses consist of both innate and adaptive immunity. However, adaptive immunity is only found in vertebrates. Thus, crustaceans, such as shrimp, do not have immunoglobulins (Namikoshi A. et al., 2004), and immune protection is mainly provided by the blood cells (Noonin C. et al., 2012). The blood cells are distributed throughout the body via circulation and play various immune defense functions, such as phagocytosis and the formation of nodules and cysts. Previous studies of artificially DIV1infected shrimp demonstrated the highest viral load in the hemolymph (Qiu L. et al., 2017). Immune cell damage in the shrimp led to decreased immune resistance and, as a result, large-scale death. The death peak of sick shrimp reared at $32 \pm 1{ }^{\circ} \mathrm{C}$ was $6 \mathrm{~h}$ earlier than that at $26 \pm 1^{\circ} \mathrm{C}$ is probably related to an increased susceptibility of the shrimp at high water temperature, making them more vulnerable DIV1 infection. However, once a series of adaptation mechanisms occurred in the shrimp, the death rate stabilized.

qPCR showed that in the early stage of DIV1 infection, the viral copy count in most tissues was higher in the $32 \pm 1^{\circ} \mathrm{C}$ group than in the $26 \pm 1{ }^{\circ} \mathrm{C}$ group, which is similar to the finding that $L$. vannamei were more sensitive to Vibrio alginolyticus infection within the first $24 \mathrm{~h}$ after transfer from 27 or $28{ }^{\circ} \mathrm{C}$ to 34 or $32{ }^{\circ} \mathrm{C}$ (Cheng W. et al., 2005). After adaptive mechanisms were induced, the shrimp could resist DIV 1 . In the $26 \pm 1{ }^{\circ} \mathrm{C}$ group, DIV1 multiplied rapidly.

This study differed from previous studies on three other major shrimp viral pathogens, WSSV, IHHNV, and TSV. In this study, DIV1 was continually replicated at standard and high-water temperatures. The DIV1 copy counts in all tested tissues at 6 hpi were marked differently from the copy counts at $24 \mathrm{hpi}$. DIV 1 infection at $26 \pm 1^{\circ} \mathrm{C}$ and $32 \pm 1^{\circ} \mathrm{C}$ led to high mortality rates of up to $95 \%$. In contrast, studies showed that warm water could inhibit the replication rates of WSSV, IHHNV, and TSV and decrease the associated mortality rates. One explanation for the inhibition is that the hyperthermic conditions facilitated apoptosis of virus-infected shrimp cells (Granja C. et al., 2003). Thus, the mechanisms of DIV1 replication in shrimp might differ from these other epidemic viruses. The conclusions that could be drawn from the results of this study are that the resulting damage to the gills and hemocytes caused by DIV1 reduced the oxygen exchange rate and immune resistance of L. vannamei (Rahman M. M. et al., 2007), and this damage could not be reduced by raising the water temperature. However, DIV1 replication and pathogenesis mechanisms have not yet been reported. Thus, further study is required to find appropriate solutions to DIV1 infection.

\section{Conclusion}

This study showed that transferring $L$. vannamei to a higher water temperature had no beneficial effect against the damage caused by DIV1 infection. The survival rate of DIV1infected L. vannamei dropped to $4.44 \%$ within $48 \mathrm{~h}$ at $26 \pm 1^{\circ} \mathrm{C}$ and to $2.22 \%$ within 30 $\mathrm{h}$ at $32 \pm 1{ }^{\circ} \mathrm{C}$. L. vannamei cultured at a high-water temperature presented a low viral load and were more susceptible to DIV1. At $32 \pm 1{ }^{\circ} \mathrm{C}$, almost all tissues reached the threshold viral load in the primary stage of infection. However, at $26 \pm 1^{\circ} \mathrm{C}$, there was a significant increase from 6 to $24 \mathrm{hpi}$, during which the copy count in each tissue increased by $10^{4}$. In conclusion, the underlying mechanism of DIV1 infection was different from WSSV, TSV, and IHHNV.

\section{Acknowledgments}

This study was supported by the 2019 annual first-class provincial special fund from the Nanhai Economic Shrimp Breeding and Breeding Laboratory (No.231419025), the Guangdong Provincial Special Fund for Modern Agriculture Industry Technology Innovation 
Teams (No.2019KJ149), Chongqing provincial financial special funds (231419025), Fangchenggang City Science and Technology Plan Project (AD19008017), the key research and development projects in Guangdong Province (2020B0202010009). We would like to acknowledge NATIVE English Editing (www.nativeee.com) for its linguistic assistance during the preparation of this manuscript.

\section{References}

Allan, E. L., Froneman, P.W., \& Hodgson, A. N., 2006. Effects of temperature and salinity on the standard metabolic rate (SMR) of the caridean shrimp Palaemon peringueyi. Journal of Experimental Marine Biology Ecology, 337(1): 103-108. Doi: $10.1016 / j . j e m b e .2006 .06 .006$

Atsushi, N., Jin, L. W., Takayoshi, Y., Toyohiko, N., Toyohiro, N., Misao, A., \& Kiyokuni, M., 2004. Vaccination trials with Penaeus japonicus to induce resistance to white spot syndrome virus. Aquatic Living Resources, 229(1-4): 25-35. Doi: 10.1016/S00448486(03)00363-6

Becker, J. \& Craig E. A., 1994. Heat-shock proteins as molecular chaperones. European Journal of Biochemistry, 219(1-2): 11-23. Doi: 10.1111/j.1432-1033.1994.tb19910.x

Cheng, W., Wang, L. U., \& Chen, J. C., 2005. Effect of water temperature on the immune response of white shrimp Litopenaeus vannamei to Vibrio alginolyticus, Aquaculture, 250(3-4): 592-601. Doi: 10.1016/j.aquaculture.2005.04.060

Chinchar, V. G., Hyatt, A., Miyazaki, T., \& Williams, T., 2009. Family Iridoviridae: Poor Viral Relations No Longer, Current Topics in Microbiology and Immunology, 328: 123-170. Doi: 10.1007/978-3-540-68618-7_4

Côté, I., \& Lightner, D. V., 2010. Hyperthermia does not protect Kona stock Penaeus vannamei against infection by a Taura syndrome virus isolate from Belize. Diseases of Aquatic Organisms, 88(2): 157-160. Doi: 10.3354/dao02131

Fouzi, M., Shariff, M., Omar, A. R., Yusoff, F. M., \& Tan, S. W., 2010. TaqMan realtime PCR assay for relative quantification of white spot syndrome virus infection in Penaeus monodon Fabricius exposed to ammonia. Journal of Fish Diseases, 33(12): 931-938. Doi: 10.1111/j.1365-2761.2010.01200.x

Granja, C., Aranguren, L., Vidal, O., Aragón, L., \& Salazar, M., 2003. Does hyperthermia increase apoptosis in white spot syndrome virus (WSSV)-infected Litopenaeus vannamei? Diseases of Aquatic Organisms, 54(1): 73-78. Doi: 10.3354/dao054073

Hernández-Palomares M. L. E., Godoy-Lugo J. A., Gómez-Jiménez S., Gámez-Alejo L. A., Ortiz R. M., Muñoz-Valle J. F., Peregrino-Uriarte A. B., Yepiz-Plascencia G., Rosas-Rodríguez J. A., \& Soñanez-Organis, J. A., 2018. Regulation of lactate dehydrogenase in response to WSSV infection in the shrimp Litopenaeus vannamei. Fish Shellfish Immunol, 74: 401-409. Doi: 10.1016/j.fsi.2018.01.011

Juliana, R. M., Diego, A. G. Á., Fernando, M. C., Trinidad, E. G., Daniel, E. C. M., Guillermo, P. C., Maria, R. F. M., Francisco, J. M. B., \& Jorge, H. L., 2012. Water temperature influences viral load and detection of White Spot Syndrome Virus (WSSV) in Litopenaeus vannamei and wild crustaceans. Aquaculture, 326: 9-14. Doi: $10.1016 / \mathrm{j}$. aquaculture.2011.10.033

Kan, L. I., Luo, S. Y., \& Li-Mei, X. U., 2013. A study on the mechanism of temperature impact on the proliferation of white spot syndrome virus (WSSV). Journal of Applied Oceanography, 32: 61-66.

Li, C. Z., Weng, S., \& He, J. G., 2019. WSSV-host interaction: Host response and immune evasion. Fish Shellfish Immunol, 84: 558-571. Doi: 10.1016/j.fsi.2018.10.043

Lightner, D. V., 1999. The Penaeid Shrimp Viruses TSV, IHHNV, WSSV, and YHV. Journal of Applied Aquaculture, 9(2): 27-52. Doi: 10.1300/j028v09n02_03

Montgomery-Brock, D., Tacon, A., Poulos, B., \& Lightner, D. V., 2007. Reduced replication of infectious hypodermal and hematopoietic necrosis virus (IHHNV) in Litopenaeus vannamei held in warm water. Aquaculture, 265(1-4): 41-48. Doi: 10.1016/j.aquaculture.2007.01.025 
Noonin, C., Lin, X., Jiravanichpaisal, P., Söderhäll, K., \& Söderhäll, I., 2012. Invertebrate hematopoiesis: an anterior proliferation center as a link between the hematopoietic tissue and the brain. Stem Cells Development, 21(17): 3173-3186. Doi: 10.1089/scd.2012.0077

Parsell, D.A., \& Lindquist, S., 1993. The function of heat-shock proteins in stress tolerance: degradation and reactivation of damaged proteins. Annual Review of Genetics, 27: 937-496. Doi: 10.1146/annurev.ge.27.120193.002253

Qiu, L., Chen, M. M., Wan, X. Y., Li, C., Zhang, Q. L., Wang, R. Y., Cheng, D. Y., Dong, X., Yang, B., Wang, X. H., Xiang, J. H., \& Huang, J., 2017. Characterization of a new member of Iridoviridae, Shrimp hemocyte iridescent virus (SHIV), found in white leg shrimp (Litopenaeus vannamei). Scientific Reports, 7(1): 11834. Doi: 10.1038/s41598017-10738-8

Qiu, L., Chen, M. M., Wang, R. Y., Wan, X. Y., Li, C., Zhang, Q. L., Dong, X., Yang, B., Xiang, J. H., \&Huang, J., 2017. Complete genome sequence of shrimp hemocyte iridescent virus (SHIV) isolated from white leg shrimp, Litopenaeus vannamei. Archives of Virology, 163(3): 781-785. Doi: 10.1007/s00705-017-3642-4

Qiu, L., Chen, M. M., Wan, X. Y., Zhang, Q. L., \& Huang, J., 2018. Detection and quantification of Shrimp hemocyte iridescent virus by TaqMan probe based real-time PCR. Journal of Invertebrate Pathology, 154: 95-101. Doi: 10.1016/j.jip.2018.04.005

Qiu, L., Chen, X., Zhao, R. H., Li, C., Gao, W., Zhang, Q. L., \& Huang, J., 2019. Description of a Natural Infection with Decapod Iridescent Virus 1 in Farmed Giant Freshwater Prawn, Macrobrachium rosenbergii. Viruses, 11(4): 354. Doi: 10.3390/v11040354

Rahman, M. M., Corteel, M., Alday-Sanz, V., Pensaert, M. B., Sorgeloos, P., \& Nauwynck, H.J., 2007. The effect of raising water temperature to $33^{\circ} \mathrm{C}$ in Penaeus vannamei juveniles at different stages of infection with white spot syndrome virus (WSSV). Aquaculture, 272(1-4): 240-245. Doi: 10.1016/j.aquaculture.2007.07.228

Suantika, G., 2013. The Use of Indigenous Probiotic Halomonas aquamarina and Shewanella algae for White Shrimp (Litopenaeus vannamei Boone) Hatchery Productivity in Zero Water Discharge System. Journal of Aquaculture Research Development, 4(5): 18. Doi: $10.4172 / 2155-9546.1000194$

Thitamadee, S., Prachumwat, A., Srisala, J., Jaroenlak, P., Salachan, P., Sritunyalucksana, K., Flegel, T., \& Itsathitphaisarn, O., 2015. Review of current disease threats for cultivated penaeid shrimp in Asia. Aquaculture, 452: 69-87. Doi: $10.1016 / \mathrm{j}$.aquaculture.2015.10.028

Tran, L., Nunan, L., Redman, R. M., Mohney, L. L., Pantoja, C. R., Fitzsimmons, K., \& Lightner, D. V., 2013. Determination of the infectious nature of the agent of acute hepatopancreatic necrosis syndrome affecting penaeid shrimp. Diseases of aquatic organisms, 105(1): 45-55. Doi: 10.3354/dao02621

Vidal, O. M., Granja, C. B., Aranguren, F., Brock, J. A., \& Salazar, M., 2001. A Profound Effect of Hyperthermia on Survival of Litopenaeus vannamei Juveniles Infected with White Spot Syndrome Virus. Journal of the World Aquaculture Society, 32(4): 364372. Doi: $10.1111 / j .1749-7345.2001 . t b 00462 . x$

Walker, P. J., \& Mohan, C. V., 2009. Viral disease emergence in shrimp aquaculture: origins, impact and the effectiveness of health management strategies. Reviews in Aquaculture, 1(2): 125-154. Doi: 10.1111/j.1753-5131.2009.01007.x

Wyban, J., Walsh, W. A., \& Godin, D. M., 1995. Temperature affects growth, feeding rate, and feed conversion of the Pacific white shrimp (Penaeus vannamei). Aquaculture, 138(1-4): 267-279. Doi: 10.1016/0044-8486(95)00032-1

Xu, L., Wang, T., Li, F., \& Yang, F., 2016. Isolation and preliminary characterization of a new pathogenic iridovirus from redclaw crayfish Cherax quadricarinatus. Diseases of Aquatic Organisms, 120: 17-26. Doi: 10.3354/dao03007

Ye, T., Tang, W., \& Zhang, X., 2012. Involvement of Rab6 in the regulation of phagocytosis against virus infection in invertebrates. Journal of Proteome Research, 11(10): 4834-4846. Doi: 10.1021/pr300274k 